\title{
The Publishers Press of Montreal
}

\author{
Carl Spadoni
}

The history of Canadian publishing has unquestionably witnessed many more failures than successes. To a great extent, this has been due to the inherent risks of publishing in Canada (small markets, high costs of distribution, etc.) In other instances, however, failure can be attributed to human folly, greed, or ignorance. An interesting example of the latter kind of failure is the short-lived venture of the Publishers Press of Montreal in I9II-I2. The only known contemporary account of the firm's activity and demise is contained in a note in S.E.D. Shortt's The Search for an Ideal:

[Andrew] Macphail was associated with Archibald MacMechan, Stephen Leacock, and a few other Canadian writers in a firm called Publishers' Press. Its function was to match the authors' manuscripts with interested publishers. It appears to have operated on its initial capital until the manager, Epstein, having collected a large salary, declared the group insolvent and its backers liable for the debts incurred while operative. ${ }^{1}$

According to Macphail, the firm's intended scope of operation was even narrower than that indicated by Shortt. 'The original design ... was an admirable one,' he explained to MacMechan when the company was on the verge of being liquidated, 'namely, to provide the Canadian periodicals with Canadian writing. ${ }^{2}$ In point of fact, the Publishers Press operated under a much wider mandate. The company acted as a syndication agency for newspaper and journal articles. Shortly after the company was incorporated, printing equipment was purchased by the manager, but nothing is known about the company's activity as a printing house. At least one book is known to have been published with the firm's imprint, Leacock's Nonsense Novels (I9I I), although copies were imported from the British publisher John Lane. Unfortunately, the story of the company's brief, disastrous life can only be partially reconstructed because the company's records are not extant.

A little is known about the firm's manager, Max Joseph Epstein. According to the second edition of The Canadian Men and Women of Our Time, Epstein was born in Munich in 1878 and was educated at the city's univer- 
sity. His profession is given as journalist and business man. He was the proprietor of the Eastern Press Service, the president and editor of the Canadian Newspaper Syndicate, and the president in I909 of the British and Colonial Press Service, and was also said to have been a 'special correspondent for leading European newspapers.' The entry goes on to mention that appreciation of his services has been recorded by many leading Canadian newspapers and that his contribution to the newspaper industry has been referred to in debate in the House of Commons. ${ }^{3}$ Prior to coming to Montreal, it would appear that he also worked in several North American cities, in particular Ottawa and New York. ${ }^{4}$

Epstein's having worked in the United States may be relevant. The year I9 Io saw the end of a monopoly which the Canadian Pacific Telegraphs had on the distribution of international news in Canada. Canadian Pacific Telegraphs owned the Canadian rights to the Associated Press reports, the major source of news from the United States and overseas. In I907, however, the Winnipeg newspapers rebelled against this monopoly by dealing with rival American press co-operatives. One of these was the Publishers' Press Association, a struggling agency which served morning dailies, mainly in the Atlantic states, and was then absorbed by the United Press Associations in June $1907 . .^{5}$ The name, Publishers Press, may very well have been borrowed by Epstein from this defunct American agency.

Epstein incorporated the Publishers Press by letters patent at Ottawa on 2 I January I9II. The company's capital stock was valued at \$150,000, divided into I, 500 shares of $\$$ Ioo each. At the time Epstein owned approximately 75 percent of the shares, and he acted in various roles - director, manager, vice-president, and secretary-treasurer. Initially, there were two other directors, Brunnk and Watkins, who worked as Epstein's employees and presumably owned the remainder of the stock. The company's charter of incorporation consists of thirteen related clauses giving the firm a wide sphere of interest in publishing with an emphasis on newspaper and magazine publication and syndication. ${ }^{6}$ Three days after the company was incorporated, Epstein purchased second-hand printing equipment ('les diverses machines et machines stéréotype et électrotype') from the William Lloyd Machinery Company of Chicago. The equipment arrived in April, and payment by installments was supposed to be completed by the end of June. Although \$2,764.66 had been paid before I 5 June I9I I, Epstein was unable to pay the balance by the end of the month. The contract for the equipment was re-negotiated in terms of a chattel mortgage. In effect this meant that Epstein was to rent the equipment until he was able to pay the balance. Epstein's difficulty in paying the William Lloyd Machinery Company in full was not an isolated incident in the turbulent history of the Publishers Press. It was probably due to financial mismanagement of this sort that he turned 
to selling the company's stock as a solution. The shareholders were completely unaware of the company's problems until it was much too late.

'It has occurred to me that possibly your Semite friend, Epstein, might like to "syndicate" one, or two, or a series of letters on the Coronation and concurrent events,' MacMechan wrote to Macphail at the beginning of I9I I, approximately a week before Epstein had incorporated the company. Edward vir had died on 6 May I9ro, and George v had succeeded him and was to be crowned on 22 June I9I I. MacMechan was planning a European tour during the summer of I9II which was to include the coronation ceremony and celebration. 'Do you think the guileless Israelite would entertain the proposition at all?' MacMechan queried. 'Would he accord a professor, a miserable, grovelling professor, a living wage? Could it be arranged by letter, or should I see the Ebrew Jew personally? ${ }^{\prime 8}$ Macphail was successful in interceding on MacMechan's behalf. 'He is a good merchant and buys an article as a trader would buy a pig on the hoof, quite willing to risk the result,' he told MacMechan about Epstein's entrepreneurial spirit. But there was a cautionary note in Macphail's reply: 'I take an interest in his scheme so that he may be prevented from going astray, as he has a very powerful engine and might do harm unless he were wisely guided. ${ }^{\prime 9}$ In due course, when Epstein wrote and gave his consent to the proposal, MacMechan was overjoyed at the prospect of 'flying round Europe' and was effusive about Epstein's 'magnificent, incredible, delightful scheme.'10 MacMechan apparently returned from Europe in September and spent three days in Montreal before going home to Halifax. While in Montreal during this time, or perhaps earlier in the summer, he had met Epstein who told him 'that he [Epstein] and L. [Leacock] were going on a gorgeous trip to Europe next summer [I9I2] and [would] make the money fly. ${ }^{\prime 11}$ MacMechan had also talked with Leacock. According to MacMechan, Leacock had emphasized to Epstein the importance of honesty in conducting business negotiations. ${ }^{12}$

One can only speculate as to the reasons for the association of the trio, Macphail, MacMechan, and Leacock, with Epstein and the Publishers Press. In I907 Macphail was appointed to the chair of medical history at McGill University and assumed the editorship of the University Magazine. Prior to his installation as editor, the journal (then titled the McGill University Magazine) resembled 'an older college publication, that had died from sheer bulk, the kind of literary dropsy that attacks the writing of professors. ${ }^{13}$ Macphail's ambition was to transform the journal into a vehicle of literary, political, and intellectual commentary 'to establish a standard of literature instead of imitation and pedantry. ${ }^{14}$ Sponsored by the universities of McGill, Dalhousie, and Toronto, the University Magazine was initially responsible to an editorial committee. 'After a meeting or two, the magazine became and remained Andrew Macphail. ${ }^{15}$ Not only did Macphail control 
the magazine's literary content, but by October 1908 he had 'taken over the business management ${ }^{\prime 16}$ as well, and on occasion, thereafter, he was forced to bail it out with funds from his own pocket. Throughout its history, the magazine was also plagued by staffing and circulation difficulties. Having initiated a policy of payment for accepted articles, Macphail attracted contributors such as Rudyard Kipling, Arthur Balfour, and J.S. Woodsworth, although most of the writing came from academics. Macphail's association with the Publishers Press is probably explained by his desire to obtain the best articles possible for the University Magazine. 'The country is full of articles such as our own,' he pointed out to MacMechan. 'It is as it was with the prophet who saw seven thousand of his fellows upon the hillside when his eyes were opened. ${ }^{17}$

As for MacMechan and Leacock's association with the Publishers Press, both men were close friends of Macphail and were frequent contributors to the University Magazine. 'His persuasive powers were great,' Pelham Edgar wrote in reminiscence of Macphail, 'with the result that MacMechan from Dalhousie and I from Toronto associated ourselves with the enterprise [the magazine]. ${ }^{18}$ Among other things, MacMechan was well known for his weekly column of social commentary and literary review, 'The Dean's Window, ' which appeared in the Montreal Standard. His investment in the Publishers Press was not his first financial commitment to a literary venture. During the I89os he was a shareholder in Goldwin Smith's influential periodical, The Week. A member of the original editorial board of the University Magazine, Leacock later co-edited the magazine when Macphail spent the war years with the Army Medical Corps in Europe. Although Leacock had found an eager English publisher in John Lane for his first book of comic genius, Literary Lapses (I9Io), the Canadian edition of the book was a piece of vanity publishing. Lacking a Canadian publisher, it would appear that Leacock thought of his investment in the Publishers Press, at least in part, as a self-serving vehicle for his future books of humour.

The first indication that Macphail, MacMechan, and Leacock received of trouble on the horizon occurred near the end of November I9II. Prior to that time, they had not been apprised of Epstein's inability to pay for the printing equipment which he had obtained from the William Lloyd Machinery Company. There had been a minor incident during the summer which they also were unaware of involving the wrongful dismissal of one of the company's employees. Having been promised a job by Epstein in writing, Joseph Charbonneau had quit his long-standing job at the Boston Post and had moved to Montreal. He had subsequently been dismissed by Epstein on the grounds of incompetence when in reality there had been no work for him to do. Charbonneau successfully sued Epstein for lost wages. ${ }^{19}$ But, on 20 November I9I I, Macphail noticed a short article in the Montreal Stan- 
dard which he immediately brought to MacMechan's attention. On a warrant issued by the Dominion Newspaper Syndicate, Epstein had been charged with illegally selling syndicate pages of Christmas matter to western publications. He was released on his own recognizance pending trial several days later. ${ }^{20}$ No further reports of the case are to be found in relevant sources. Epstein was probably convicted and duly fined. He was doing business again several weeks later. ${ }^{21}$

MacMechan was much disturbed by the news of Epstein's arrest. The legal responsibility of being a director of the Publishers Press worried him considerably: 'Possibly I too (and you my fellow director) may come within the curb of old father Antic the law. ${ }^{22}$ Especially irksome to MacMechan was the fact that he had induced a number of his Halifax friends to buy shares in the firm. He sincerely hoped that Epstein's arrest did not augur inauspiciously for the company's financial well-being. Macphail's reply contained mixed news: 'I am afraid he [Epstein] is incapacitated for further good by his very crookedness. My lawyer advises me and Leacock that none of the directors were legally appointed. This includes yourself, so that no responsibility attaches. Also he used the names of persons as being directors who had never signified or assented, and some who had actually declined.' Contrary to his own wishes, Macphail, for example, had been dubbed by Epstein as the company's Vice-President. Notwithstanding Epstein's dishonesty, Macphail believed that the affair was self-contained and would not infect the operation of the company. His advice to MacMechan was: 'Let not your heart be troubled about Epstein, but do not pay him any money. ${ }^{23}$

In the meantime, however, Epstein had apparently taken another drastic step. 'One woe is past,' MacMechan lamented 'and behold another woe cometh quickly.' Epstein had taken MacMechan's shares (valued at \$ I,Ooo) to the Eastern Townships Bank, 'refusing to sign notes or accept drafts, but agreeing to pay \$ 40.xx / Ioo per month for the said stock.' MacMechan had made only one downpayment on the shares. Epstein's precipitous action raised the distinct possibility that MacMechan would hand over his 'extra earnings to that concern and at the end have nothing to show for ... [his] outlay. ${ }^{24}$ It was not just MacMechan who had been placed in this disconcerting position. 'My Brother [Alexander Macphail, Chairman of the Department of Civil Engineering at Queen's, later editor of Queen's Quarterly] is in the same situation and he was induced to subscribe under false pretences,' Macphail informed MacMechan. ${ }^{25} \mathrm{He}$ urged MacMechan not to make any further payments and to refer all requests for payment to a Montreal firm of lawyers which he and Leacock had contacted.

From December I9I I to April I9I 2 the fate of the Publishers Press hung in the balance with various parties attempting to gain control of it, to reconstitute it, or to declare it insolvent. 'The trouble about the Publishers' Press 
is, that it is so good that several interests are striving to acquire it, and I cannot tell which will win, ${ }^{\prime}$ Macphail commented. ${ }^{26}$ Residing outside of Montreal, MacMechan felt impotent to alter the course of events, and he could only monitor the situation from the reports in Macphail's letters. Shareholders of the company met frequently during this period, but the meetings were not always fruitful forums of information and discussion. Initially the status of the company appeared confusing: 'I went to a meeting of shareholders which was called for ten days ago but Epstein did not turn up,' Macphail reported, 'so I really do not know how things stand save that neither you nor I have any responsibility in the matter. ${ }^{.27} \mathrm{~A}$ meeting held on 26 December I9I I helped to clarify the situation a little, but it did not resolve the many doubts of the shareholders. The purpose of the meeting was:

To present a statement of the Company; To elect Directors and Officers of the Company; To discuss a settlement with the William Lloyd Machinery Co. of Chicago, and any other business which might properly come before this meeting. ${ }^{28}$

The meeting did produce 'some remarkably free speaking.' The statement which was issued purported that the company was basically sound and stable, 'but I did not believe the statement,' Macphail added 'and that disbelief seemed to be shared by all present. ${ }^{29} \mathrm{~A}$ bright spot was that Epstein had promised to surrender all his stock to the company's treasury. Macphail saw this as an opportunity to save the company and to reconstruct it on a new footing. Other shareholders were not so optimistic, however.

The situation came to a head in January r9r2. Lieutenant Colonel William Charles Henry Wood, the author of The Fight for Canada (1904), The Logs of the Conquest of Canada (1909), and Tercentennial Quebec (I9II) to name only a few of his many historical works - presented a petition in court to declare the Publishers Press insolvent. Macphail backed by Leacock presented a counter petition to have the affairs of the company examined by a trust company. Macphail's petition was granted, and the Prudential Trust Company was appointed to make the required investigation. Macphail was now hopeful that with a little more capital and honest management, the Publishers Press could be salvaged. He rested such hopes on two facts: that his brother-in-law, Colonel J.H. Burland, happened to be the President of the Prudential Trust Company, and that Epstein had been removed from the firm's operations, having returned all of his shares. ${ }^{30}$

Macphail's hopes were soon dashed. 'I have spent the most of my spare time for the past month over this thrice accursed business of the Publishers' Press,' he complained bitterly. The Prudential Trust Company advised 'that it would be unsafe to attempt to carry on the present company because 
no one can tell what obligations still exist and which might be disclosed just as soon as we get into working order. ${ }^{31}$ With one battle lost, Macphail thought that if the war over the Publishers Press could not be won, it was still possible to make the best of a bad situation. Since the Publishers Press could not be revitalized, he wanted to create a new company and to issue new stock in exchange for the old. His only qualm was that he had paid $\$ 600$ for shares in the Publishers Press, but this amount had not been credited to his stock subscription. Legally he was in a poor position to recover any of his money in terms of shares in the new company.

Unfortunately, Macphail's attempt to form a new company proved futile. Although Epstein had surrendered his stock, he was not about to give up his interests in the Publishers Press without a fight. Colonel Wood had learned how Epstein planned to regain control. 'I think I am right to warn you that Epstein is recommending shareholders of P.P. $\mathrm{L}^{\text {td }}$ to give their proxies to Desmarteau for the meeting on the $22^{\mathrm{d}}$ [February I912]. Bishop Dunn sent me his notice, and Quebecers are on their guard, knowing what Epstein is.' For Wood, what was at stake was more than just mere money. 'The point, above and beyond all other considerations, is distinctly a point of honour.... No man of honour can associate with him [Epstein] in business, under any circumstances whatever, even if the business is entirely successful - which P.P. L $^{\text {td }}$ emphatically is not.' Wood implored Macphail to cut his losses entirely. He was surprised that a person of Macphail's experience could be so easily duped. Shareholders had invested in the Publishers Press primarily because they had complete confidence in Macphail's integrity. 'I only wish the business side of P.P. $\mathrm{L}^{\text {td }}$ had been shown to you originally,' Wood ruefully remarked. 'I remember your saying a year ago that you knew nothing except about the literary side. Then we might all have been saved, and P.P. $\mathrm{L}^{\text {td }}$ would never have suffered from Epstein's besmirching methods. ${ }^{32}$

What exactly happened at the shareholders' meeting on 22 February is not known. 'At least three parties are trying to get hold of the institution [the Publishers Press],' Macphail reported to MacMechan 'and they are especially anxious to conciliate the writers, such as you, and Leacock, and me, because they realize that Epstein certainly had a fine literary support.' The three parties were Epstein who wanted to reinstate himself, Wood who would make no pact with the devil and wanted to dissolve the company absolutely, and Macphail who wished to reorganize the firm into a new one, 'issuing preferred stock to those who put fresh money in and issuing common stock to those who appear to have been swindled by the old management.' Macphail was somewhat uncertain whether he could actually count on Colonel Wood's support because Colonel Wood was relying on one of Epstein's former associates: 'Richards who is acting for Col. Wood was once in Epstein's employ and so was Muir. Richards I understand has some 
proxies which he promises to turn over to us but I doubt it when the time comes. ${ }^{33}$ All three parties were attempting to secure enough proxy votes to take control of the company's power of decision-making.

Macphail and Wood apparently joined forces and successfully thwarted Epstein's move. 'We are having regular meetings of the Publishers' Press, and the last will be the middle of this month,' Macphail told MacMechan at the beginning of March. 'Epstein is out and a new man has acquired his shares with the intention of putting money into the concern and carrying it on in proper fashion. He is merely waiting to verify the accounts. ${ }^{34}$ These few sentences would lead one to think that Macphail's point of view had prevailed. Several weeks later, however, the last mention of the Publishers Press in the Macphail-MacMechan correspondence concludes on a dismal note:

Do you remember the churlish reply of a man to John Wesley's salutation? 'Good morning' said the preacher, and the answer was 'I wish you was in hell.' I say the same about Epstein. A man has been found who is considering the taking over of the business, but he is yet considering. I am sorry I have nothing more cheerful to say to you. ${ }^{35}$

According to the law report of the William Lloyd Machinery Company's suit against the Publishers Press for failure to pay for printing equipment, the Publishers Press was liquidated sometime in April I9I2. The two liquidators were supposedly Epstein's associates, Brunnk and Watkins. ${ }^{36}$ This report conflicts with Macphail's account found in a letter to MacMechan. In Macphail's account, the liquidator was George Macdonald, the auditor of McGill University, and an advisory committee consisted of Macphail, Leacock, and Burland. ${ }^{37}$ When Frank Wise, the President of the Macmillan Company of Canada, wrote to Macphail at the beginning of May I9I 2 and asked him, 'By the way what has become of your Epstein syndicate?' Macphail tersely replied, 'The Epstein company is broken up hopelessly. ${ }^{\prime 38}$

In the debacle of the Publishers Press, Leacock fared worse than his fellow directors. Besides losing the money he invested in the company's stock, he was defrauded by Epstein over the publication of Nonsense Novels, Leacock's second book of humour. With respect to the comic sketches of the book, Leacock would later remark: 'The stories in this book I wrote for a newspaper syndicate in I9 I0. ${ }^{39}$ It is likely that the syndicate in question is the Publishers Press, but nothing further is known as to what extent the stories were syndicated. His literary parodies, originally titled 'Novels in Nutshells,' appeared serially in I9 Io-I I in the Toronto magazine, Saturday Night. Sometime in I9I I Leacock arranged for Epstein to import copies from John Lane for the Canadian edition of the book. The title page of the 
Canadian edition is integral and has the imprint 'CANADIAN EDITION/ PUBLISHERS' PRESS, LIMITED / MONTREAL / I9II.' 'The matter is rather complicated as far as I and the Publishers' Press are concerned,' Lane explained to Leacock's solicitor 'by the fact that though they had Professor Leacock's books from me I charged them by agreement to Professor Leacock who in turn charged them to the Publishers' Press.... ${ }^{40}$ In February I9I2 when the status of the company was uncertain, Epstein sent Lane a cheque for $\$ 220$ to cover the cost of books from London and New York. The cheque should have been sent directly to Leacock. There were insufficient funds to cover the cheque, and Lane surmised that under the circumstances Epstein had sent the cheque not by mistake but in order to gain time. The account was never made good by the Publishers Press. Leacock paid the amount due out of his own pocket. He also arranged for Musson to distribute the Canadian edition. 'I have delivered 500 copies of "Nonsense Novels" to the Musson Book Co. since you told me you had given them the market,' Lane confirmed with Leacock 'but I am unable to charge the books to them and I do not know at what price you charged them before. ${ }^{41}$ Ostensibly, the binding of the Musson issue in dark green cloth with stamped white lettering is the same for all copies. Copies of this issue contain advertisements from John Lane which are missing from the Publishers Press edition. In some copies of the Musson issue, the imprint on the title page is the Publishers Press or John Lane (I9I2, 3d ed.). In others Musson has substituted its own cancel title page.

Unfortunately, for Macphail, his bad experience with the business side of publishing was repeated in I9I3, a year after the liquidation of the Publishers Press. Besides editing the University Magazine, he had assumed the editorship of the Canadian Medical Association Journal which first appeared in I9II. The publisher of both serials was George Morang and Company. With respect to the Canadian Medical Association Journal, Morang 'apparently appropriated subscription fees to which he was not entitled and refused to issue reprints' of articles. ${ }^{42}$ In addition, Morang advertised medical products of dubious efficacy. Legal proceedings initiated by the Canadian Medical Association proved to be a successful countermeasure to Morang's practices. With regard to the University Magazine, however, Macphail had invested his own money in keeping the magazine afloat. Although Macphail's money was held in a trust account, Morang had gained access to the account and had left Macphail with a deficit of $\$ 3,800$. Threat of legal action against Morang was ineffective, and Macphail never recovered the debt owed. In January I9I 2 there were 5,300 paid subscribers to the University Magazine; by December I9I3, due to Morang's 'autocratic methods,' over 3,000 subscribers were lost. ${ }^{43}$

It was Macphail's philosophical view that business destroys what it 


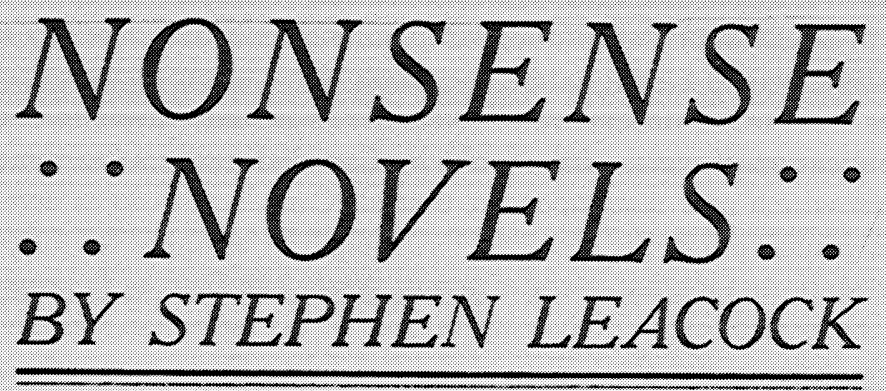

$$
\begin{gathered}
\text { CANADIAN EDITION } \\
\text { PUBLISHERS PRESS, LIMITED } \\
\text { MONTREAL } \\
\text { I9: }
\end{gathered}
$$

The title page of the Canadian issue of Stephen Leacock's Nonsense Novels, the only known book bearing the imprint of the Publishers Press. 
touches - 'religion, friendship, love, education, literature, art ... wither and die. ${ }^{\prime 44}$ In S.E.D. Shortt's opinion, Macphail's intellectual hostility to commercialism was to a great extent the result of his bitter relationships with Morang and the Publishers Press. ${ }^{45}$ Macphail's aspiration was to undertake the publication of worthwhile books by Canadian writers, 'to remove the discredit which now rests upon us, that all Canadian books of any importance are made out of the country. ${ }^{\prime 46}$ Although he arranged for the publication of Marjorie Pickthall's collection of verse, The Drift of Pinions (1913), under the imprint of the University Magazine, his aspiration was never realized. However minor the failure of the Publishers Press may appear in the history of Canadian publishing, the venture reflects Macphail's strong belief that 'unless Canadian publishing houses ... [take] charge of all publications for Canadian authors, they ... [have] very little reason for existence. ${ }^{47}$

NOTES

I S.E.D. Shortt, The Search for an Ideal: Six Canadian Intellectuals and Their Convictions in an Age of Transition, 1890-1930 (Toronto and Buffalo: University of Toronto Press, I976), p. I 59, note 82. I am indebted in this paper to the two chapters in Shortt's book on Macphail and MacMechan. The spelling of the word 'Publishers' varies in pertinent documents and correspondence and often occurs with an apostrophe, i.e. Publishers'.

2 Macphail to MacMechan, I7 Jan. I9I2, Dalhousie University Library, Halifax, Nova Scotia (hereafter NSHD).

3 Henry James Morgan, ed., The Canadian Men and Woman of Our Time, $2 \mathrm{~d}$ ed. (Toronto: William Briggs, I9I2), p. 377. The entries for Leacock (p. 645) and Macphail (p. 7 I 8) in this biographical reference tool list both men as being directors of the Publishers Press, Ltd.

4 William Wood to Macphail, I4 Feb. I9 12, Public Archives of Canada, MG 30 D I 50 (hereafter PAC). 'Epstein has a foul record in New York, Montreal and Ottawa.'

5 M.E. Nichols, (CP): The Story of the Canadian Press (Toronto: The Ryerson Press, I948), pp. 26, 49; Alfred McClung Lee, The Daily Newspaper in America: The Evolution of a Social Instrument (New York: The Macmillan Co., 1937), pp. $520,536$.

6 I have been unable to find anything on Epstein's two employees, Brunnk and Watkins, not even a mention of their first names. The company's charter of incorporation can be found in The Canada Gazette (I9II), pp. 2425-26.

7 The William Lloyd Machinery Company versus the Publishers Press, Limited, (ro Jan. I9I4), Les rapports judiciaires de Québec 23 (I9I4): I84-92.

8 MacMechan to Macphail, I3 Jan. I9I I, PAC. Even though MacMechan's letter may have been written in jest, the tone and wording of his letter are patently anti-semitic.

9 Macphail to MacMechan, I6 Jan. I9 I I, NSHD.

Io MacMechan to Macphail, 29 March I9I I, PAC.

I I MacMechan to Macphail, 29 Nov. I9I I, PAC.

I2 MacMechan to Macphail, 23 Nov. I9I I, PAC. 'Why is E. [Epstein] crooked, when there is no need of crookedness. Leacock told me this summer that he had put it very straight to $\mathrm{E}$. Is he hopeless?' 
I3 Leacock, 'Andrew Macphail,' Queen's Quarterly 45 (winter I938-39): 449. For an opposite assessment of the McGill University Magazine, see Peter F. McNally, 'The McGill University Magazine, I90I-I906: An Evaluation and a Bio-bibliographical Analysis' (M.A. Research Paper, McGill University, I976). See also McNally's 'Canadian Periodicals and Intellectual History: The Case of the McGill University Magazine/University Magazine, I90I-I920,' Papers of the Bibliographical Society of Canada I9 (I980): 69-78.

I4 Macphail to MacMechan, 2 April I907, NSHD. See also Pelham Edgar, 'Sir Andrew Macphail,' Queen's Quarterly 54 (Spring I947): 8-9. 'He [Macphail] wished to interest some of the leading universities in the production of a magazine that would adequately serve the intellectual needs of the country, and might conceivably shape its opinion.'

I5 Leacock, op. cit., p. 450. See also Macphail, 'Stephen Leacock' in The Year Book of Canadian Art, 1913, The Arts \& Letters Club of Toronto, comps. (London and Toronto: J.M. Dent \& Sons, n.d.), pp. 3-7.

I6 Macphail to MacMechan, I9 Oct. I908, NSHD.

I7 Macphail to MacMechan, 2 April I907, NSHD.

I8 Edgar, op. cit., p. 9. See also MacMechan's poem of tribute entitled 'Andrew Macphail' in MacMechan's Late Harvest (Toronto: The Ryerson Press, I934), p. 5 I.

I9 Joseph Charbonneau versus the Publishers Press, Limited, (17 Feb. 1912), Les rapports judiciaires de Québec 42 (I912): 97-107; and La revue légale n.s. I8 (I9I 2): 4IO-I 5 .

20 'Montreal Publisher Arrested,' Montreal Standard, i 8 Nov. I9I I supplement, p. r.

2 I See Macphail to MacMechan, I2 Dec. I9II, NSHD.

22 MacMechan to Macphail, 23 Nov. I9I I, PAC.

23 Macphail to MacMechan, 25 Nov. I9I I, NSHD.

24 MacMechan to Macphail, 29 Nov. I9I I, PAC.

25 Macphail to MacMechan, I Dec. I9I I, NSHD.

26 Macphail to MacMechan, I2 Feb. I9I 2, NSHD.

27 Macphail to MacMechan, I 2 Dec. I9I I, NSHD.

28 Publishers Press to MacMechan, I I Dec. I9I I, NSHD.

29 Macphail to MacMechan, 26 Dec. I9II, NSHD.

30 Macphail to MacMechan, 8 Jan. I9I2, NSHD.

3 I Macphail to MacMechan, I7 Jan. I9I2, NSHD.

32 Wood to Macphail, 4 Feb. I9I 2, PAC. The Rev. Edward Arthur Dunn was Lord Bishop of Quebec and editor of the Quebec Diocese Gazette. I have been unable to discover the identity of Desmarteau. See The Canadian Men and Women of Our Time, pp. $355-56$.

33 Macphail to MacMechan, 7 Feb. I9I2, NSHD. It is not clear what role Richards and Muir played in this intrigue. It is conceivable, though unlikely, that Muir is Robert Cuthertson Muir (I 856-I 935), a business man and historian who eventually settled in Quebec and wrote The Early Political and Military History of Burford (I9I3). See The Macmillan Dictionary of Canadian Biography, ed. W. Stewart Wallace and W.A. McKay, 4th ed. (Toronto: Macmillan, I978), p. 603.

34 Macphail to MacMechan, I March I9I2, NSHD.

35 Macphail to MacMechan, 25 March I9I2, NSHD.

36 Les rapports judiciaires de Québec 23 (I9I4): I87-88. The suit was originally heard in the Quebec Superior Court on 30 Sept. I9 I2. The decision was against the William Lloyd Machinery Company. ('la requérante a fait défaut de prover sa propriété desdites machines et son droit d'en réclamer la possession contre les 
liquidateurs.') The judgement was appealed and reversed on I4 Jan. I9I4, and the William Lloyd Machinery Company reclaimed the printing equipment and was awarded court expenses.

37 Macphail to MacMechan, I 7 Jan. I9 I 2, NSHD.

38 Wise to Macphail, 6 May I9I2, and Macphail to Wise, 7 May I9I 2, Mills Memorial Library, McMaster University, Hamilton, Ontario (hereafter OHM).

39 Quoted by Peter McArthur, Stephen Leacock (Toronto: The Ryerson Press, 1923), p. 9. See also the acknowledgment in Literary Lapses (Montreal: Montreal News Company Limited, I9 I I), pp. 247-48 and later editions of this book: 'The Articles "How to Make a Million Dollars" and "How to Avoid Getting Married," etc. are reproduced by permission of the Publishers' Press Syndicate.'

40 Lane to Warwick Chipman, 2 I Feb. I9 I2, Stephen Leacock Memorial Home, Orillia, Ont. Chipman belonged to the Montreal firm of Brown \& Montgomery. 'He is the one who writes so admirably in the Magazine,' Macphail told MacMechan, I7 Jan. I9I 2, NSHD.

4I Lane to Leacock, 2 I Feb. I9I2, Stephen Leacock Memorial Home. Lane convinced Leacock to give Bell \& Cockburn the Canadian rights to Sunshine Sketches of a Little Town. See Lane to Leacock, 8 March I9 I 2, Stephen Leacock Memorial Home. 'I hope that you will see your way later on if not now to give Bell \& Cockburn the line of your books. They have shown very great enterprise, they are good payers and I think that I shall be able to arrange when in Canada early in May for them to take all my books in future. It will so simplify things. Musson I feel has too many irons in the fire.' Musson, however, did publish a Canadian issue of Literary Lapses in I9r 3.

42 S.E.D. Shortt, 'Sir Andrew Macphail: Physician, Philosopher, Founding Editor of CMAJ,' Canadian Medical Association Journal I i 8 (4 Feb. I978): 324.

43 Macphail to MacMechan, 2 Jan. I9I 2, NSHD; Wise to Macphail, I 3 June I9I3, and Macphail to Wise, I4 June I9I3 and I Dec. I913, онм.

44 Macphail, 'Consequences and Penalities,' University Magazine I 3 (I9I4): 172.

45 S.E.D. Shortt, The Search for an Ideal, p. I 59, note 82.

46 Macphail to MacMechan, 24 Dec. I9I3, NSHD.

47 Macphail to MacMechan, 30 Jan. I9I4, NSHD.

Illustration is courtesy of the William Ready Division of Archives and Research Collections, McMaster University, Hamilton, Ontario, Canada. 